\title{
Insecticide Residues in Soil, Water, and Eggplant Fruits and Farmers' Health Effects Due to Exposure to Pesticides
}

\author{
Jinky Leilanie Del Prado-Lu
}

Received: 28 April 2014/ Accepted: 11 November 2014/Published online: 21 November 2014

(c) The Japanese Society for Hygiene 2014

\begin{abstract}
Objectives Eggplant (Solanum melongena L.) is an important vegetable crop that is widely cultivated in the tropical and subtropical areas in Asia. Globally, the top three eggplant producers are China, India, and Egypt. The Philippines has been one of the top 10 eggplant-producing countries based on area planted and crop productivity. This study aims to describe the insecticide residues found in soil, water, and eggplant fruits in eggplant farms in Sta. Maria, Pangasinan.

Methods The study design is a cross sectional of randomly selected eggplant farms in Sta. Maria, Pangasinan. Soil, water, and eggplant fruits were collected and subjected to gas chromatography (Shimadzu) analysis for multi-pesticide residues.

Results Farmers from Sta. Maria, Pangasinan were found to be applying a broad spectrum of insecticides on their eggplant crop. Soil samples from 11 (about $42 \%$ ) out of the 26 farms tested positive for insecticide residues, six of which from four farms exceeded the acceptable maximum residue limit. These residues were profenofos, triazophos, chlorpyrifos, cypermethrin, and malathion. No insecticide residues were detected from water samples taken from the 26 farms. Cypermethrin and chlorpyrifos were the insecticide residues detected in eggplant fruit samples. A maximum of
\end{abstract}

Electronic supplementary material The online version of this article (doi:10.1007/s12199-014-0425-3) contains supplementary material, which is available to authorized users.

J. L. Del Prado-Lu ( $)$

Institute of Health Policy and Development Studies, National Institutes of Health, University of the Philippines Manila, NIH Bldg, P. Gil St., UP Manila, Taft Avenue, 1100 Manila, Philippines

e-mail: jinky_lu@yahoo.com
$20 \%$ of the eggplant samples tested positive for insecticide residues. In the eggplant fruit study, all farmers have been using Prevathon ${ }^{\circledR}$ for 24 years at a rate of $10 \mathrm{ml} /$ application, and Malathion ${ }^{\circledR}$ for 25 years at about $16.5 \mathrm{ml} /$ application, respectively equivalent to 0.24 liter-years and 0.413 literyears of exposure. Similarly, to the findings in the soil and water study, although Brodan ${ }^{\circledR}$ and Magnum ${ }^{\circledR}$ were not prevalently applied, the farmers' liter-years of exposure to these insecticides, and their active ingredients, were highest at about 18.92 and 10.0, respectively. The farmers and farm workers in the soil and water study reported experiencing itchiness of the skin (63.8\%), redness of the eyes $(29.3 \%)$, muscle pains $(27.6 \%)$, and headaches $(27.6 \%)$, as being related to their pesticide exposure.

Conclusion In summary, a maximum of $20 \%$ of the eggplant samples tested positive for insecticide residues at any one stage of sampling done. The farmers and farm workers also reported of pesticide-related illnesses but none of them sought any medical attention. Intervention to reduce the farmers' pesticide exposure can focus on the risk factors identified, primarily the toxicity of pesticides used, the unsafe application practices, and the adverse health effects of pesticide exposure.

Keywords Insecticide residues - Environmental samples · Eggplant · Agriculture · Spraying

\section{Introduction}

Eggplant (Solanum melongena L.) is an important vegetable crop that is widely cultivated in the tropical and subtropical areas in Asia. Globally, as of 2007, the top three eggplant producers are China with 18 million tons ( $\mathrm{t}$ ), India with 8.5 million $\mathrm{t}$, and Egypt with 1 million $\mathrm{t}$. In the 
same year, the Philippines was one of the top 10 eggplantproducing countries based on area planted and crop productivity (Supplementary Table 1) [1].

During 2006-2011 in the Philippines, eggplant was consistently the leading vegetable crop in terms of production, which increased by $8.4 \%$ from about $192,000 \mathrm{t}$ in 2006 to nearly $208,000 \mathrm{t}$ in 2011 . In the same period, area planted increased by $2.3 \%$ from about 20,900 hectares (ha) in 2006 to almost 21,400 ha in 2011, while its yield increased by almost $6 \%$ from 9.2 tons per hectare (t/ha) to $9.7 \mathrm{t} / \mathrm{ha}$ (BAS 2013). In 2011, the top five eggplant producing provinces in the Philippines are Pangasinan, Quezon, Iloilo, Isabela, and Cagayan (in this order). Pangasinan provided almost $31 \%$ of the country's total eggplant production and accounted for about $18 \%$ of the total area planted. However, at 17.0 t/ha, eggplant yield in Pangasinan was only half of the yield level in Quezon province in 2011 (Supplementary Table 2) [2].

Like many other crops, eggplant-from seedling to fruiting stage-is susceptible to damage by various insects and diseases, among which the fruit and shoot borer (FSB) (Leucinodes orbonalis Guenee) has caused yield losses of 20-92 \% in the Philippines (Francisco 2009). FSB is a pink, sesame seed-sized moth larva that feeds on eggplant stems and fruits from the inside out (Bleicher 2009). This insect also bores into the terminal shoots, causing the shoots to wither thus delaying the crop's vegetative development [3].

To control FSB, farmers resort to frequent and heavy spraying of insecticides. Informal interviews with eggplant farmers in the Philippines found cases of spraying at 60-80 times during a normal fruiting duration of at least 4 months (Francisco 2009). Similarly in India, farmers sprayed an average of 20-30 times per crop season at about 26.7 L (li)/ ha of "cocktail" pesticides, such as chlorpyrifos, cypermethrin, monocrotophos, and dimethoate [1, 4]. Manual removal of damaged fruits and shoots has proven to be effective, yet it is rarely adopted because it is labor intensive.

However, since FSB larvae are internal feeders, control through chemical pesticide application is often futile and even presents high risks of environmental degradation and contamination. The literature is rich with reports and studies confirming that injudicious pesticide use in agricultural crop production can pose environmental problems such as soil and water contamination; pest tolerance or resistance; damage to non-target organisms and biodiversity loss; excessive chemical exposure for applicators; and health risks for consumers.

In the present work, two studies were conducted to determine insecticide residues first in the soil and water, and second in eggplant fruits in Sta. Maria, Pangasinan, the top eggplant producing province in the Philippines. More specifically, the studies aimed to:

1. Determine the nature of insecticide residues that can be found in the soil and water in eggplant farms, and detect and quantify residues in eggplant fruits;

2. Determine the soil properties that influence the persistence and mobility of insecticides in the soil and water through literature review;

3. Differentiate insecticide residues in eggplant fruits in three stages: farm for immature fruit prior to harvesting, post-harvest, and market, and between two cropping seasons (July to August for wet season, and September to June for dry season, following the Department of Agriculture standard);

4. Evaluate the level of insecticide residues detected in the soil, water, and eggplant fruits against maximum residue limits (MRLs) set by local and international authorities [e.g., Codex Alimentarius, Environmental Protection Agency (EPA), European Union Commission (EC)]; and

5. Determine implications of insecticide exposure to health of farmers/applicators and insecticide residue in eggplants on health of consumers.

\section{Materials and methods}

The two studies were cross sectional designs of randomly selected eggplant farms in Sta. Maria, Pangasinan, established based on the sample size estimation equation below:

$n=\frac{\mathrm{NZ}^{2} \times p(1-p)}{\mathrm{N} d^{2}+\mathrm{Z}^{2}[p(1-p)]}$

where:

$\mathrm{Z}$ is the value of the normal variable for a reliability level, set at $90 \%$ reliability in this study, considering budget and feasibility;

$p$ is the proportion of getting a positive sample based on previous studies, set at 0.20 ;

$1-p$ is the proportion of getting a negative sample based on previous studies, set at 0.80 ;

$d$ is the sampling error, set at 0.10 ;

$\mathrm{N}$ is the population size (128 eggplant farms, as of 2010 per Municipal Agricultural Office of Sta. Maria, Pangasinan); and

$n$ is sample size.

Source: Bautista, Victoria [5].

Based on the above estimation equation, 26 farms were selected from six villages (barangays) for the soil and water study, with a total of 58 farmers and farm workers who 
participated in the health assessment aspect. The eggplant fruit study was conducted in Sta Maria, Pangasinan with another group of 10 farms, whose farmer-owners were interviewed about production practices and insecticide exposure factors. Medical doctors conducted health profiling and assessment of the 68 farmer-respondents.

\section{Sample collection}

\section{Soil and water}

A total of twenty-six soil samples were collected. One field soil sample and another replicate sample were taken from each of the 26 farms. Each sample weighed 1 kilogram of soil. In one farm, a final sample of soil was drawn from well-mixed samples of soil collected at different plotting, then placed in an opaque plastic bag, and taken for laboratory analysis. A soil auger was used to get the soil samples from a depth of 1 meter. The sampling standard operating procedure recommended by the Philippine Department of Agriculture for soil sampling is one meter depth.

Similarly, 26 field water samples and another 26 replicate samples were taken from various sources such as river, irrigation canal, and drinking water system located within the 26 sample farms. There were a total of 26 samples from all the 26 farms. There was one sample in each farm. The replicate was used merely as a back-up sample. Each water sample had a volume of $2 \mathrm{~L}$. Two samples/replicates of the soil and water samples and one field blank were collected from each farm. All soil and water samples were placed in an icebox, and delivered to the laboratory within $24 \mathrm{~h}$. The samples were stored in a laboratory refrigerator at a temperature of $5{ }^{\circ} \mathrm{C}$, and analyzed using gas chromatography.

\section{Eggplant fruits}

A total of twelve samples of $1 \mathrm{~kg}$-eggplant (six $1-\mathrm{kg}$ samples per farm, two replicates) were taken from various plotting within each of the 10 sample farms. For each farm, each replicate group of six 1-kg eggplant samples were mixed well together, and a final 1-kg eggplant sample was drawn, placed in an icebox, and delivered within $24 \mathrm{~h}$ which was the standard operating procedure for laboratory analysis. In the laboratory, the samples were stored in a freezer at a temperature of $-20{ }^{\circ} \mathrm{C}$.

Sample analysis and quality control

A standard laboratory procedure was used to analyze the material samples (BPI 2008). Briefly, the insecticide residues were desorbed from the samples and analyzed using gas chromatography operated in a split mode. Major chromatogram peaks were identified in the samples by comparing retention times and mass spectra to peaks from a calibration method.

In the gas chromatography analysis for multi-pesticide residues in the soil and eggplant samples, two detectorsnitrogen phosphorous and electron capsule detectorswere used. Solid phase extraction was done using acetonitril. The vegetable samples underwent a three-stage clean up to remove particulates and impurities. The first clean up stage used C18; the second, carbon graphite; and the third and final stage used flourisil. The water sample underwent both liquid-liquid extraction, and one solid phase extraction using $\mathrm{C} 18$ as water samples are cleaner than soil samples. The elements in the oven program such as the temperature programming, retention time of various pesticides, and temperature of the detector were previously determined and depended on each type of pesticide. The recovery method was $70-100 \%$. The coefficient of variation was less than $10 \%$. Two trials were done for each sample. The limit of determination (LOD) for organophosphates was $0.02 \mathrm{mg} / \mathrm{kg}$, and $0.005 \mathrm{mg} / \mathrm{kg}$ for organochlorines and pyrethroids.

The research was registered with the Research Grants Administration Office of the National Institutes of Health, and the Research Ethics Board stipulated that the research study would have been exempted from ethics clearance as it mainly focused on environmental samples and with minimal risk.

\section{Results and discussion}

A combined total of 36 eggplant farmers were interviewed in the two studies: 26 farmers from barangays Samon, Cabagbagan, Nauplasan, Cal-litang, and Pilar for the soil and water study, and 10 farmers from the same barangays except Cal-litang for the eggplant fruit study. All farms in the eggplant study were included in the water and soil study.

The farmer-respondents in the studies reported that fruit and shoot borer is the most common pest of eggplants in their communities. Other pests that have been encountered were aphids, bacterial wilt, blight, and thrips. To control the various pests in eggplant production, farmers used different pesticides, each of which targets a range of pests (Supplementary Table 3). Conversely, the farmers also used different insecticides (e.g., Brodan ${ }^{\circledR}$, Lannate $^{\circledR}$, Malathion ${ }^{\circledR}$, Prevathon ${ }^{\circledR}$, and Tamaron ${ }^{\circledR}$ ) to control fruit and shoot borer.

Most, if not all, farmer-respondents in the soil and water study used Prevathon ${ }^{\circledR}$ (active ingredient chlorantraniliprole), Malathion ${ }^{\circledR}$ (malathion), and Lannate ${ }^{\circledR}$ (methomyl). In terms of amount used per application, Brodan ${ }^{\circledR}$ 
(chlorpyrifos) came on top at 264 milliliters $(\mathrm{ml})$, followed by Siga $^{\circledR}$ (chlorpyrifos) at $183 \mathrm{ml}$, and Malathion ${ }^{\circledR}$ at $173 \mathrm{ml}$. On average, the farmers used $77 \mathrm{ml}$ of insecticide per application. See Table 1.

Similar to the above findings, most farmer-respondents in the eggplant fruit study used Prevathon ${ }^{\circledR}$ and Malathion $^{\circledR}$, but Magnum ${ }^{\circledR}$ had the highest application rate at 2 L/application, with Brodan $^{\circledR}$, a distant second highest at $473 \mathrm{ml} /$ application. (These application rates appear to be outliers, as the other insecticides were used at a range of 2.5-20.0 ml/application.) If Magnum ${ }^{\circledR}$ and Brodan ${ }^{\circledR}$ are included, the mean amount used per application is $235 \mathrm{ml}$; if excluded, the mean amount used is about $12.8 \mathrm{ml} /$ application. The 26 farmer-respondents in the soil and water study have been using pesticides for almost 9 years, on average, while the 10 farmer-respondents in the eggplant fruit study have been using them for nearly 23 years (Tables 1 and 2). Looking more closely, all farmerrespondents in the soil and water study have been using Prevathon ${ }^{\circledR}$ for about 3 years at a rate of $68 \mathrm{ml} /$ application, equivalent to 0.212 liter-years of exposure. Although Brodan $^{\circledR}$ and Siga ${ }^{\circledR}$ were not prevalently applied, the farmers' liter-years of exposure to the active ingredients of these insecticides were highest at about 3.036 and 2.948, respectively. See Table 2 .

In the eggplant fruit study, all farmers have been using Prevathon ${ }^{\circledR}$ for 24 years at a rate of $10 \mathrm{ml} / \mathrm{appli}$ cation, and Malathion ${ }^{\circledR}$ for 25 years at about $16.5 \mathrm{ml} /$ application, respectively equivalent to 0.24 liter-years and 0.413 liter-years of exposure. Similarly, to the findings in the soil and water study, although Brodan ${ }^{\circledR}$ and Magnum ${ }^{\circledR}$ were not prevalently applied, the farmers' liter-years of exposure to these insecticides, and their active ingredients, were highest at about 18.92 and 10.0, respectively. See Table 2.

\section{Multimedia monitoring of pesticide}

Multimedia monitoring of contaminants such as insecticides is an essential part in investigating the entire spectrum of environmental contamination. In this study, three media were assessed and these are the eggplant fruits, soil samples and water samples. This is due to the fact that pesticides can infiltrate air, oceans, rivers, groundwater, and soil [6]. They can also move into other areas away from sites of application, such as to water bodies through runoff, soil through adsorption and leaching, and air through spray/vapor drift [7]. For instance, Varca in 2002 found that, during application, only around $15 \%$ of the pesticides applied on crops hit the target organism; a larger proportion is distributed in the soil and air [8]. It is the inherent characteristics of selected insecticides and their environmental fate in soil, water, air, and plants that explains why this study looked into multi-media monitoring of insecticides (Supplementary Table 4).

The fate of insecticides and their transformation products (TPs) in the soil depend on the properties of their active ingredients and degree of interaction with the soil particles (or adsorption). Parameters such as water solubility, soil-sorption constant (Koc), octanol/water partition coefficient (Kow), and half-life of insecticides in the soil (DT50), as well as properties such as chemical functions, polarity, polarizability, and charge distribution of both soil and insecticide molecules measure the persistence and movement of insecticides and their TPs in the soil [9-12] (Supplementary Table 5). In this study, insecticide residues with low polar characteristics and detected in the soil samples were chlorpyrifos, cypermethrin, malathion, profenofos, and triazophos (Supplementary Table 5).

Insecticides vary in toxicity, persistence of active ingredients and mobility, and thus also pose differing degrees of environmental risks [13]. An insecticide with low sorption coefficient, long half-life, and high water solubility has the potential to contaminate groundwater through leaching [12]. Half-life, the typical measure for persistence, ranges at 10-100 days for modern pesticides. Insecticides with longer half-lives have active ingredients or residues that stay longer in the environment, posing more danger to other non-target organisms [13-18].

Sediments can serve as a sink of pesticide residues, increasing the risks of bioavailability and accumulation in the food chain through resuspension. The soil, as the main reservoir of pesticide residues, poses toxicity to terrestrial and benthic organisms [19]. In California, residues of permethrin, fenvalerate, bifenthrin, lamba-cyhalothrin were detected in sediment samples [20]. In the Philippines, chlorpyrifos residues were found in soil samples in Benguet and were associated with muscle fasciculations among the local farmers [21].

\section{Insecticide residue analysis of soil and water}

In general, the soil serves as a "purifying filter" that influences pesticide contamination of groundwater. The soil profile plays a significant role in determining the chemical's leachability to the groundwater, and soil organic content on pesticide persistence. However, modern technology has developed pesticides that are more watersoluble, thermolabile, polar, and persistent, to better enable effective pest control. These may explain why pesticide compounds, specifically herbicides, have been detected in surface and ground waters [12, 13, 22, 23].

Residues of five insecticides were detected in the soil of 11 farms (42\%) among the 26 sample farms. Profenofos and triazophos were found in three and six eggplant farms, respectively, some at levels exceeding the acceptable 


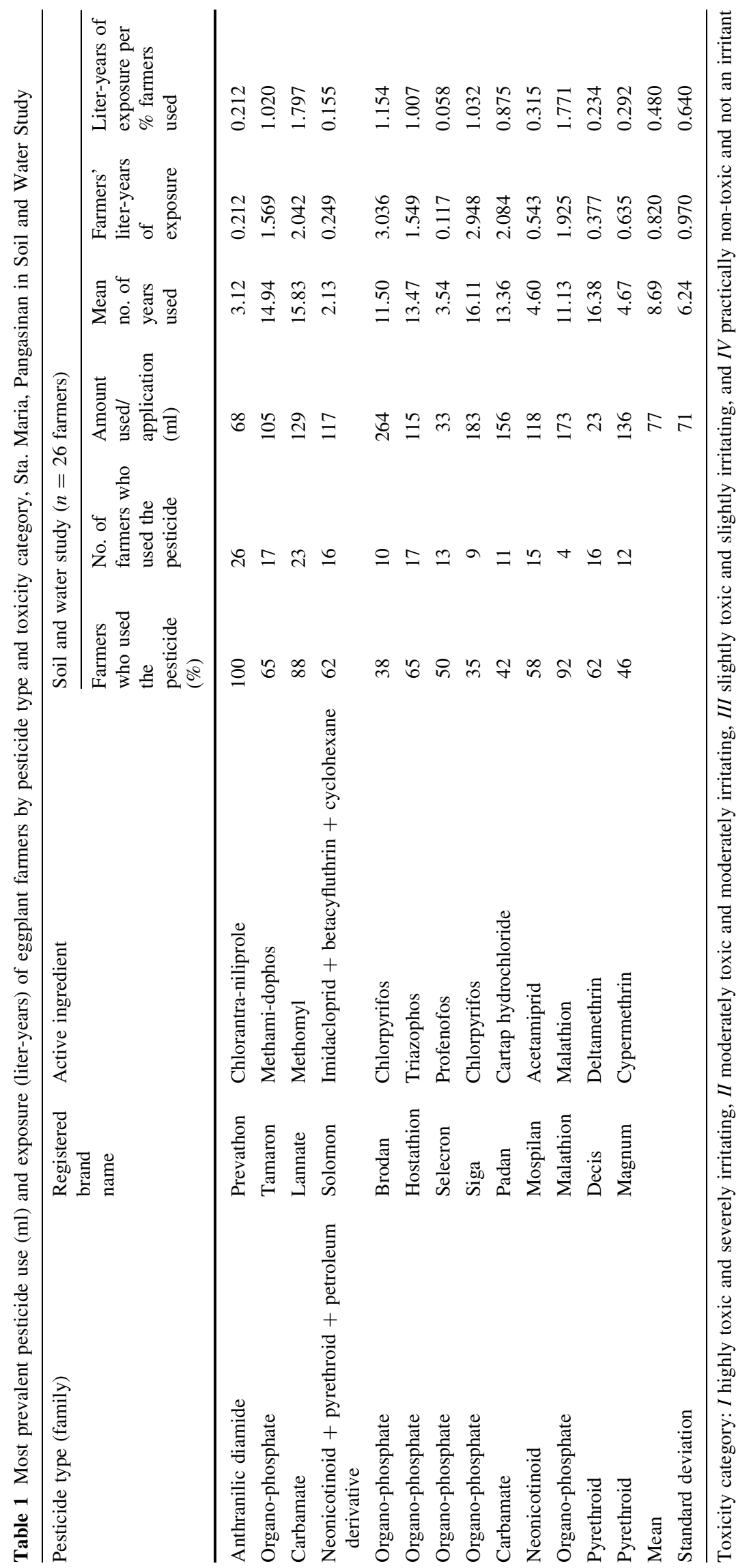




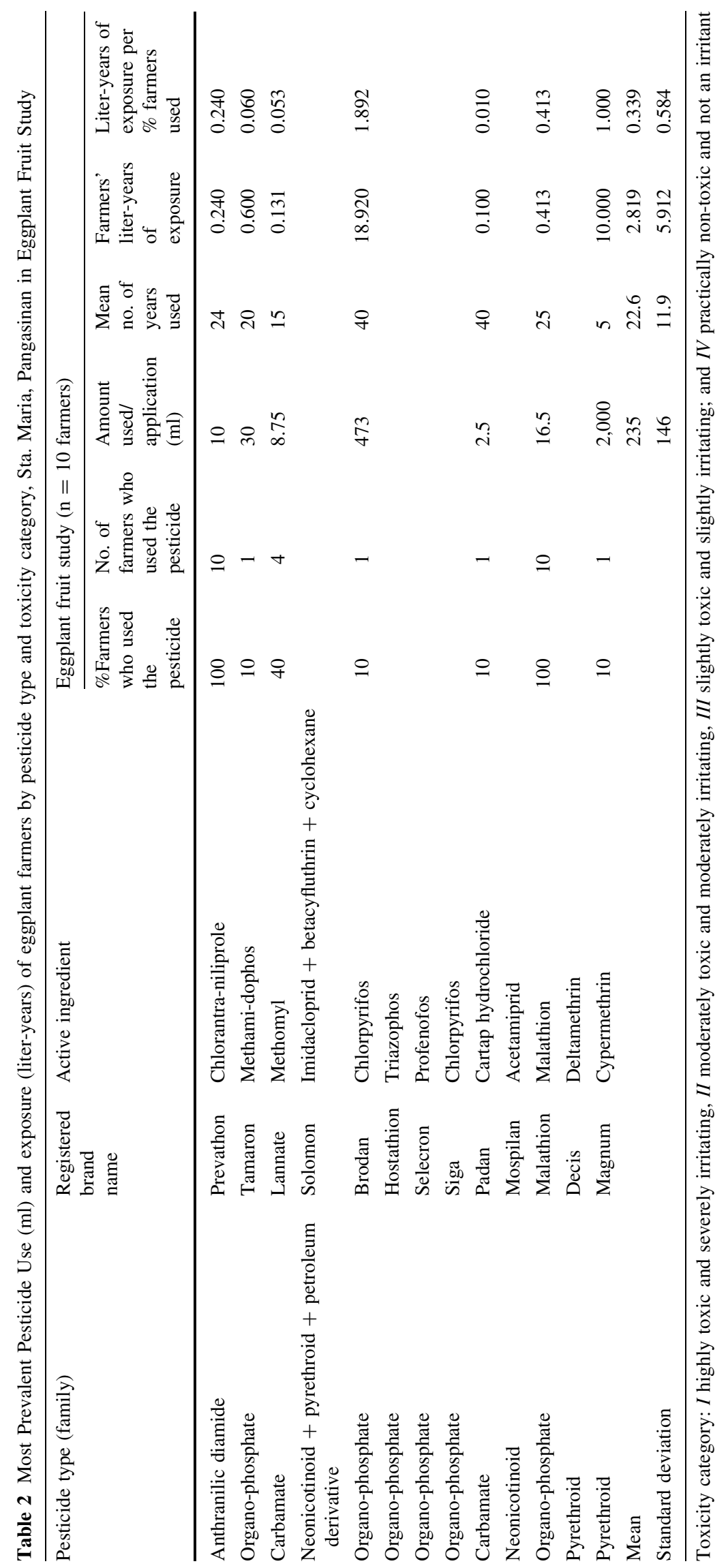


maximum residue limit (MRL) set by the European Commission (EC) and/or the US Environmental Protection Agency (EPA). One farm had $0.10 \mathrm{ppm}$ of profenofos in the soil, which is twice the acceptable MRL (Table 3). Four farms had $0.02-0.05 \mathrm{ppm}$ of triazophos, which is higher than the $0.01 \mathrm{ppm}$ MRL. Chlorpyrifos, cypermethrin, and malathion were each found in two farms, although none of them exceeded the MRL. These results have been influenced by the insecticides' behavior in the soil, as indicated by their mobility, leachability, persistence, and volatility. None of the water samples was found positive with insecticide residues. Almost all of the insecticide residues detected in the soil have high Koc and hence low leaching potential. The compound's movement is therefore limited throughout and over the soil profile, such that there is less potential for groundwater contamination.

In contrast, the sources of drinking water of farmers in Southwestern part of Nigeria had been found contaminated with diazinon and propouxr at concentrations exceeding the acceptable daily intake (ADI) [24]. In Laguna and Nueva Ecija provinces, both in the Philippines, residues of pesticides including chlorpyrifos, butachlor, endosulfan, carbofuran, methyl parathion, and monocrotrophos were detected in groundwater samples taken from tube wells adjacent to rice fields [25]. In this study, the deep wells where farmers get their drinking water are possibly contaminated with pesticide residues, because they are located near the farms. Pesticide residues in water bodies such as streams and rivers may affect fishes, birds, wild animals, and plants in the aquatic habitat. Pesticides are usually lipophilic and hydrophobic in nature, making them easily accumulate and magnify in biological tissues of organisms progressing up the food chain $[26,27]$. Some pesticides can be bioaccumulated in tissues of aquatic animals, move through the food chain, and eventually be ingested by and adversely affect birds, wild animals and domestic livestock. Examples are the thinning of egg shells of bald eagles [28, 29], and reproductive depression in aquatic biota in Dar es Salaam, Tanzania [30-32]. In Ghana, pesticide residues in the farmlands along the Densu River banks washed into the river when it rained, and bioaccumulated in the tissues of fishes found therein [33]. In Edo
State, Nigeria, higher levels of lindane and aldrin residues were found in fishes than in water samples [34].

\section{Insecticide residue analysis of eggplant fruits}

All of the farmers in the eggplant fruit study reported applying Prevathon (chlorantraniliprole, anthranilic diamide) and Malathion (malathion, organophosphate) to control pests in their eggplant crops. However, farmers used Brodan (chlorpyrifos, organophosphate) at the highest average rate of $473 \mathrm{ml} /$ application, followed by Magnum (cypermethrin, pyrethroid) at an average of $30 \mathrm{ml} /$ application. Tamaron (methamidophos, organophosphate) was also reported as used at an average of $30 \mathrm{ml} /$ application.

Of the 10 sample farms, wet season sample eggplants in 2 farms were detected as having chlorpyrifos and cypermethrin, with the former at a level higher than the prescribed maximum residue level (Table 4). Similarly, cypermethrin was detected in harvested eggplants from 2 farms, with levels within the prescribed limit. From the dry season analysis, cypermethrin was detected from samples in 2 farms, and also from harvested eggplants in 1 farm, at levels equal to the prescribed limit. All market samples from both wet and dry seasons tested negative for insecticide residues. In summary, a maximum of $20 \%$ of the eggplant samples tested positive for insecticide residues at any one stage of sampling done.

Pesticide residues in plants may reach the consumers through ingestion of raw foods [35]. Various surveys around the world found that $50-70 \%$ of vegetables are contaminated with insecticide residues, which plant roots absorbed from contaminated soils and migrated to edible parts [36]. In Tanzania for example, Mwevura et al. [32] found high levels of organochlorine pesticide residues in edible biota in coastal areas. In India, Mukherjee and Gopal [37] detected residues of fenvalerate, tau-fluvalinate, lamba-cyhalothrin, and monocrotophos in eggplant fruits. In the United States, endosulfan sulfate was the most prevalent $(16.76 \%)$ pesticide residue found in eggplants, followed by endosulfan II $(12.8 \%)$ and metamidophos (4.5\%) [38].
Table 3 Summary results of insecticide residue analysis in the soil and water of 26 eggplant farms, Sta. Maria, Pangasinan

a There were more than one insecticide found in one farm

\begin{tabular}{lllllll}
\hline Sample & $\begin{array}{l}\text { No. of samples (with } \\
\text { replicates) }\end{array}$ & \multicolumn{2}{l}{ Positive for insecticide residues } & & \multicolumn{2}{l}{$\begin{array}{l}\text { Insecticide residues exceeding } \\
\text { MRL }\end{array}$} \\
\cline { 3 - 4 } & $\begin{array}{l}\text { No. of } \\
\text { farms }\end{array}$ & $\begin{array}{l}\text { No. of insecticides } \\
\text { found }\end{array}$ & $\begin{array}{l}\text { No. of } \\
\text { farms }\end{array}$ & $\begin{array}{l}\text { No. of insecticides } \\
\text { found }\end{array}$ \\
\hline Soil & 26 & $11(42.3 \%)$ & $19(73.1 \%)^{\mathrm{a}}$ & & $4(15.4 \%)$ & $6(23.1 \%)^{\mathrm{a}}$ \\
Water & 26 & 0 & 0 & 0 & 0 \\
\hline
\end{tabular}


Table 4 Percentage distribution of positive residues in eggplants in various stages, Sta. Maria, Pangasinan

\begin{tabular}{lll}
\hline $\begin{array}{l}\text { Stages of } \\
\text { sampling }\end{array}$ & \multicolumn{2}{l}{ Crop seasons } \\
\cline { 2 - 3 } & $\begin{array}{l}\text { Wet } \\
\text { season }\end{array}$ & $\begin{array}{l}\text { Dry } \\
\text { season }\end{array}$ \\
\hline $\begin{array}{c}\text { Farm } \\
\text { samples }\end{array}$ & $20 \%$ & $20 \%$ \\
$\begin{array}{c}\text { Harvest } \\
\text { samples }\end{array}$ & $20 \%$ & $10 \%$ \\
$\begin{array}{c}\text { Market } \\
\text { samples }\end{array}$ & - & - \\
\hline
\end{tabular}

\section{Health profile of eggplant farmers}

Detectable concentrations of insecticide residues in soil, water (both groundwater and surface water), air, and even commodities pose risks to human health and the environment $[35,36]$. A study of farming families with houses within 200 feet from their farms detected higher concentrations of organophosphorous pesticides (including chlorpyrifos, parathion, phosmet, and azinphosmethyl) in the household dust than those found in the farm soils [37]. In this study, the residents are potentially exposed to household dust- and soil-contaminated insecticides since houses are very close to the farms.

The 58 farmers and farm workers in the soil and water study and 10 farmer-respondents in the eggplant fruit study were interviewed on their medical history and health profile, and a medical doctor conducted their physical health assessment. Table 5 shows the health concerns (complaints) that the respondents reported as related to their application of agricultural pesticides.

The farmers and farm workers in the soil and water study reported experiencing itchiness of the skin $(63.8 \%)$, redness of the eyes $(29.3 \%)$, muscle pains $(27.6 \%)$, and headaches $(27.6 \%)$, as being related to their pesticide exposure. Meanwhile, the farmer-respondents in the eggplant fruit study reported experiencing headaches (40\%), itchiness of the skin $(30 \%)$, and burning sensation of the skin $(30 \%)$. While all the respondents reported getting (or feeling) sick immediately after applying pesticides to their eggplant crops, none of them sought any medical attention. The clinical manifestations of the farmer-respondents indicate that, with complaints of mild symptoms without obvious cholinesterase depression based on blood chemistry, only mild pesticide poisoning has occurred. In more severe instances, tremors, abdominal cramps, excessive urination, bradycardia, staggering gait, pinpoint pupils, and hypotension may be observed [38]. Significant effects of pesticide exposure have also been reported on motor or neuromuscular involvement, with symptoms that may include paresthesia, convulsions, tremors, ataxia, local or general fasciculation, and tremors [39]. Intervention to reduce the farmers' pesticide exposure can focus on the risk factors identified earlier, primarily the toxicity of pesticides used, and their unsafe application practices. All these health symptoms have been reported in other researchers on pesticide exposure in relation to adverse health affectations [39-45].

Skin is the most exposed organ of the body. Farmers are exposed to pesticides during mixing and loading the pesticides, spraying them in the fields, as well as when disposing empty pesticide containers and cleaning the spray equipment. In the eggplant fruit study, the farmer-respondents reported possibly having had dermal contact $(100 \%)$, respiratory exposure $(90 \%)$, and ocular contact $(50 \%)$ with the pesticides during preparation and/or field application. Related to exposure through skin contact, reports of pesticide-related dermatoses are recently increasing. These include allergic or irritant contact dermatitis, and rare clinical forms such as urticaria, erythema multiforme, ashy dermatoses, parakeratosis variegata, and porphyria cutanea tarda, chloracne, nail and hair disorder [39]. These various routes of exposure of insecticidesdermal, ocular, respiratory, oral- are affected by the physicchemical characteristics of pesticides.

\section{Conclusion}

Across the soil and water and eggplant fruit studies covered in this study, farmers from Sta. Maria, Pangasinan were found to be applying a broad spectrum of insecticides on their eggplant crop. These consisted of 25 commercial brands, with two being category I (highly toxic) pesticides; nine category II (moderately toxic) pesticides; and seven each of categories III and IV (respectively, slightly toxic and practically non-toxic) pesticides. Soil samples from 11 (about $42 \%$ ) out of the 26 farms tested positive for insecticide residues, six of which from four farms exceeded the acceptable maximum residue limit. No insecticide residues were detected from water samples taken from the 26 farms. From the eggplant fruit study, residues of two commercial insecticides were detected in the samples.

Pesticide residues can remain as environmental pollutants in the soil, water, and even air, and impact flora and fauna, including humans and human health. The studies' findings suggest that environmental monitoring including in water, groundwater, soil, air, and plants for pesticide residues ought to be promoted and institutionalized, especially in key agricultural production areas and communities. Insecticide monitoring in eggplants can be done simultaneously with soil and water monitoring since some insecticides can leach into the soil and even groundwater.

Farmers also ought to be made better aware of the environmental and human health impacts of pesticide use 
Table 5 Health profile of eggplant farmers and the corroboration with other studies

\begin{tabular}{|c|c|c|c|c|}
\hline \multicolumn{3}{|c|}{ Health profile of eggplant farmers } & \multirow[t]{2}{*}{ Corroboration with other studies } & \multirow[t]{2}{*}{ References } \\
\hline $\begin{array}{l}\text { Health } \\
\text { symptoms }\end{array}$ & $\begin{array}{l}\text { Soil and } \\
\text { water study } \\
(\%)\end{array}$ & $\begin{array}{l}\text { Eggplant } \\
\text { study }(\%)\end{array}$ & & \\
\hline $\begin{array}{l}\text { Skin } \\
\text { itchiness }\end{array}$ & 63.8 & 30 & \multirow{3}{*}{$\begin{array}{l}\text { Dermal irritation considered as a potential acute pesticide } \\
\text { exposure hazard, with pesticide-related dermal symptoms such } \\
\text { as dermal rashes, damaged fingernails, contact dermatitis, } \\
\text { urticaria, skin hypopigmentation and hair disorders; also } \\
\text { integumentary abnormalities }\end{array}$} & $\begin{array}{l}\text { Spiewak [39]; Cantor and } \\
\text { Young-Holt [40] }\end{array}$ \\
\hline Eye redness & 29.3 & - & & \multirow{5}{*}{$\begin{array}{l}\text { Iishii-Eitemann and Ardhianie } \\
\text { [41] } \\
\text { Clarke et al. [42]; Nordin et al. } \\
\text { [43]; Yassin [44]; Lekei and } \\
\text { Ngowi [45] }\end{array}$} \\
\hline Muscle pain & 27.6 & - & & \\
\hline Headache & 27.6 & 40 & $92 \%$ of the farmers complained of health-related problems right & \\
\hline \multirow[t]{2}{*}{$\begin{array}{l}\text { Burning } \\
\text { sensation of } \\
\text { the skin }\end{array}$} & & 30 & $\begin{array}{l}\text { after applying pesticides, including tiredness, weakness, } \\
\text { dizziness, nausea, vomiting, blurred vision, rashes, itchy skin, } \\
\text { burning sensations in the throat, chest pain, and difficulty of } \\
\text { breathing }\end{array}$ & \\
\hline & & & $\begin{array}{l}\text { Dizziness, headache, skin irritation, and burning sensation on the } \\
\text { face were reported by farmers in Malaysia, Ghana, Gaza strip, } \\
\text { and Tanzania. Eye tearing or eye redness is also common, as } \\
\text { well as nausea and salivation for gastrointestinal symptoms }\end{array}$ & \\
\hline
\end{tabular}

and exposure, and encouraged to practice more judicious pesticide application, and to observe proper and safer application practices. These farmer education/awareness campaigns could be led by the municipal agriculture office, with support from and coordination with other concerned stakeholders, both from the public sector and the private sector (e.g., agricultural chemical companies). Environmental management programs can be developed and incorporated in these campaigns to minimize, if not neutralize, the potential adverse effects of contaminated soil, water, and groundwater, and promote remediation practices for contaminated such elements.

In the future, these studies could be replicated and/or scaled up to include more farmer-respondents and/or eggplant-producing communities/towns/provinces in the Philippines. Such will provide a more robust set of observations as to the variety of eggplant production practices, extent of pesticide contamination in eggplant production areas/environments, as well as of farmer exposure to pesticides applied to eggplant crops. For example, variants of these future investigations could analyze the level of insecticide residues in eggplant fruits according to farmer cultural pesticide application practices, or examine the level of pesticide residues in eggplant fruits in various stages of development up to when they are sold retail to consumers.

Lastly, more extensive research could be conducted on the transformation products of insecticides applied in eggplant production in the Philippines, looking at their fate in the soil, and the bonding forces between the soil and the pesticide active ingredient.

Acknowledgments Acknowledgement is cited for the National Institutes of Health, University of the Philippines Manila for its faculty and research facilities support, and the International Service for the Acquisition of Agri-biotech Applications for funding of this study.

Conflict of interest There was no conflict of interest in this study.

\section{References}

1. Choudhary B, Gaur K. The Development and Regulation of Bt Brinjal in India (Eggplant/Aubergine). ISAAA Brief No. 38. ISAAA, Ithaca, 2013.

2. Bureau of Agricultural Statistics (BAS). CountryStat Philippines. 2013. http://www.countrystat.bas.gov.ph. Accessed 3 May 2013.

3. AgriBusiness Week. Scientists Develop Eggplant Varieties Resistant to Fruit and Shoot Borer. 2013. http://www.agribusi nessweek.com/?s=Scientists +Develop+Eggplant + Varieties + Resistant+to+Fruit+and+Shoot+Borer. Accessed 3 May 2013.

4. Baral K, Roy BC, Rahim KMB, Chatterjee H, Mondal P, Mondal D, Ghosh D, Talekar NS. Socioeconomic Parameters of Pesticide Use and Assessment of Impact of an IPM Strategy for the Control of Eggplant Fruit and Shoot Borer in West Bengal, India. Technical Bulletin No. 37. AVRDC publication number 06-673. AVRDC-The World Vegetable Center, Shanhua, Taiwan. 2006. p 36.

5. Bautista V. Sampling techniques. UP: UP Open University, Research and Public Administration; 2000. p. 163-5.

6. Cooper S. Toxic Effects of Pesticide Residue on Fruits and Veggies. 2013. http://blog.friendseat.com/danger-of-pesticidesin-fruits-and-vegetables/. 16 Jun 2013.

7. British Columbia. Pesticide Names. 2010. http://www.agf.gov.bc. ca/pesticides/a_1.htm. Accessed 10 Jul 2010.

8. Varca LM. Pesticide Toxicology and Chemistry Laboratory. National Crop Protection Center, University of the Philippines at Los Banos, 2002. http://www.agnet.org/library/eb/520/. Accessed $10 \mathrm{Jul} 2010$.

9. Bailey GW, White JL. Factors influencing the adsorption, desorption, and movement of pesticides in soils. Residue Rev. 1970;32:29-92. 
10. Senesi N. Binding mechanisms of pesticides to soil humic substances. Sci Total Environ. 1992;123(124):63-76.

11. Pignatello JJ, Xing B. Mechanisms of slow sorption of organic chemicals to natural particles. Environ Sci Technol. 1996;30:1-11.

12. Andreu V, Pico Y. Determination of pesticides and their degradation products in soil: critical review and comparison of methods. Trends Anal Chem. 2004;23(10-11):772-89.

13. Barnard C, Daberkow S, Padgitt M, Smith ME, Uri ND. Alternative measures of pesticide use. Sci Total Environ. 1997;203:229-44.

14. Wolfe HR, Staiff DC, Armstrong JF, Comer SW. Persistence of parathion in soil. Bull Environ Contam Toxicol. 1973;10:1-9.

15. Davidson JM, Rao PSC, Ou LT, Wheeler WB, Rothwell DF. Adsorption, Movement, and Biodegradation of Large Concentrations of Selected Pesticides in Soils. USEPA, CI, 600/2-80124, 1980.

16. Schoen SR, Winterlin WL. The effects of various soil factors and ammendments on the degradation of pesticide mixtures. J Environ Sci Health. 1987;22:347-77.

17. Winterlin WL, Seiber JN, Craigmail A, Baier T, Woodrow J, Walker G. Degradation of pesticide waste taken from a highly contaminated evaporation pit in California. Arch Environ Contam Toxicol. 1989;18:734-47.

18. Gan J, Koskinen WC, Becker RL, Buhler DD. Effect of concentration on persistence of alochlor in soil. J Environ Qual. 1995;24:1162-9.

19. Food and Agriculture Organization of the United Nations (FAO). Assessing soil contamination: a reference manual. Rome: FAO Pesticide Disposal Series; 2000.

20. Weston DP, You J, Lydy MJ. Distribution and toxicity of sediment-associated pesticides in agriculture-dominated water bodies of California's Central Valley. Environ Sci Technol. 2004;38(10):2752-9.

21. Lu JL. Multipesticide residue assessment of agricultural soil and water in major farming areas in Benguet, Philippines. Arch Environ Contam Toxicol. 2010; doi:10.100/s00244-90-9748-5.2. 17.

22. Aharonson N, Cohen SZ, Drescher N, Gish TJ, Gorbach S, Kearney PC, Otto S, Roberts TR, Vonk JW. Potential contamination of ground water by pesticides. Pure Appl Chem. 1987;59:1419-46.

23. Hamilton DJ, Ambrus A, Dieterle RM, Felsot AS, Harriss CA, Holland PT, Katayama A, Kurihara N, Linder J, Unsworth J, Wong SS. Regulatory limits for pesticide residues in water (IUPAC technical report). Pure Appl Chem. 2003;75(8):1123-55.

24. Sosan MB, Akingbohungbe AE, Ojo IAO, Durosinmi MA. Insecticide residues in the blood serum and domestic water source of cacao farmers in Southwestern Nigeria. Chemosphere. 2008;72:781-4.

25. Castaneda AR, Bhuiyan SI. Groundwater contamination by ricefield pesticides and some influencing factors. J Environ Sci. Health. 1996;31(1):83-99.

26. Swackhamer D, Hites RA. Occurrence and bioaccumulation of organochlorine compounds in fish from Siskiwit Lake, Isle Royale, Lake Superior. Environ Sci Technol. 1988;22:543-8.

27. Vassilopoulou V, Georgakopoulous-Gregoriades E. Factors influencing the uptake of organochlorines in red mullet (Mullus barbatus) from a gulf of Central Greece. Mar Poll Bull. $1993 ; 26: 285-7$.
28. Lars H. Environmental exposure to persistent organohalogen and health risks. In: Lennart M editor. Environmental medicine 2000. Ch: 12 http://www.envimed.com. Accessed 3 May 2013.

29. Ibitayo O. Agricultural pesticide contamination. In: Cutler J. Cleveland editors. Encyclopedia of Earth. (Washington, D.C: Environmental Information Coalition, National Council for Science and the Environment) 2007. http://www.eoearth.org/article/ Agricultural_pesticide_contamination. Accessed 3 May 2013.

30. Helle E, Olsson M, Jensen S. DDT and PCB levels and reproduction in ringed seal from the Bothnian Bay. Ambio. 1976;5:188-9.

31. Machiwa JF. Heavy metals and organic pollutants in sediments of Dar es Salaam harbour prior dredging in 1999. Tanz. J. Sci. 2000;26:29-45.

32. Mwevura H, Othman CO, Mhehe GL. Organochlorine Pesticide Residues in Edible Biota from the Coastal Area of Dar es Salaam City Western Indian Ocean. J. Mar. Sci. 2000;1(1):91-6.

33. Afful S, Anim AK, Serfor-Armah Y. Spectrum of organochlorine pesticide residues in fish samples from the densu basin. Res $\mathrm{J}$ Environ Earth Sci. 2010;2(3):133-9.

34. Ize-Iyamu OK, Asia IO, Egwakhide PA. Concentrations of residues from organochlorine pesticide in water and fish from some rivers in Edo State Nigeria. Int J Phys Sci. 2007;2(9):237-41.

35. Lukassowitz I. Analysis and assessment of pesticide residues. Federal Institute of Risk Assessment, 2007. http://www.jstor.org/ pss/1295710. Accessed 17 Jun 2013.

36. Karanth NGK. Challenges of limiting pesticide residues in fresh vegetables: the Indian experience. Food Safety Management in Developing Countries. Proceedings of the International Workshop 11-13 2002, Montpellier, 2002.

37. Mukherjee I, Gopal M. Residue behaviour of fenvalerate, taufluvalinate, lambda-cyhalothrin and monocrotophos in eggplant (Solanum melongena L.) fruits. Pestic Sci. 1992;36(3):175-9.

38. Food and Agriculture Organization of the United Nations (FAO). Assessing soil contamination: a reference manual. Rome: FAO Pesticide Disposal Series; 2000.

39. Spiewak R. Pesticides as a cause of occupational skin diseases in farmers. Ann Agric Environ Med. 2001;8(1):1-5.

40. Cantor A, Young-Holt B, Pregnancy B. Related symptoms among farm workers in rural Honduras. Int. J Occup Environ Health. 2002;1:41-6

41. Iishii-Eitemann MJ, Ardhianie N. Community monitoring of integrated pest management versus conventional pesticide use in a World Bank project in Indonesia. Int J Occup Environ Health. 2002;8(3):220-32.

42. Clarke EEK, Levy LS, Spurgeon A, Calvert IA. The problems associated with pesticide use by irrigation workers in Ghana. Occup Med. 1997;47:301-8.

43. Nordin RB, Araki S, Sato H, Yokohama K, Muda Wan, WAMB, Win KD. Effects of Safety Behaviors with pesticide use on occurrence of acute symptoms in male and female tobaccogrowing Malaysian farmers. Ind Health. 2002;40:182-90.

44. Yassin MM, Abu Mourad TA, Safi JM. Knowledge, attitude, practice, and toxicity symptoms associated with pesticide use among farm workers in the Gaza Strip. Occup Environ Med. 2002;59:387-93.

45. Lekei EE, Ngowi AVF. Self reporting of pesticide exposure and health effects among workers at a coffee estate. Afr Newslett Occup Health Saf. 2006;16:56-8. 